\title{
About Chin (Genioplasty) Surgery
}

\author{
Sobre Cirugía del Mentón (Genioplastía)
}

\author{
Heitor Fontes da Silva ${ }^{1}$; Luide França Marinho ${ }^{1}$, Gustavo Almeida Souza ${ }^{1}$; \\ Alexander Tadeu Sverzut ${ }^{1}$, Sergio Olate ${ }^{2,3}$; Luciana Asprino ${ }^{1}$ \& Márcio de Moraes ${ }^{1}$
}

DA SILVA, H. F.; MARINHO L. F.; SOUZA, G. A.; SVERZUT, A.T.; OLATE, S.; ASPRINO, L. \& DE MORAES, M. About chin (Genioplasty) surgery. Int. J. Morphol., 38(4):1120-1127, 2020.

SUMMARY: Facial harmony is the consequence of a proper balance between all facial structures. The identification and classification of morphologic characteristics that detract from facial harmony is most effectively accomplished by clinical examination. The maintenance of the ratios between the facial thirds, correct spatial bone position and soft tissues accommodation are all factors that directly contribute in a balanced facial profile. The chin, likewise, contributes significantly in facial balance, mainly in the profile view. Expressive changes on chin position are associated with the perception of strong or delicate characters. Thus, over the years, a series of studies has been constructed focusing on mandibular osteotomies techniques that enable changes in chin position: advances, setback, extrusion, intrusion, widening, narrowing and asymmetry. This study aims to address historical and technical aspects of genioplasty; associating patient's condition with the surgical techniques that can be applied for correction of chin deformities.

KEY WORDS: Chin; Genioplasty; Orhognathic surgery; Facial aesthetic.

\section{INTRODUCTION}

Currently, the improvement of esthetics and function are important topics in surgeries to treat facial deformities. In this sense, the convexity of the facial profile within normal cephalometric measurements is considered to be more harmonic and attractive (Hönn et al., 2005; Johnston et al., 2005); on the other hand, patients with a concave profile added to maxillary hypoplasia and mandibular prognathism are considered by lay people as "less attractive and intelligent" (Sinko et al., 2012).

In most of cases, combined surgery (maxilla and mandibular osteotomy) is recommended to produce better facial harmony characteristics. However, we should not only consider cephalometric measures and maxillary and mandible profiles, since the chin is considered a central anatomical point for the harmony and convexity of the face (Rustemeyer \& Lehmann, 2013).

Hugo Obwegeser introduced bone-grafting by intraoral approach in clinical practice in 1957 and after a few years, this relatively simple technique with low morbidity rate still appears as a point of discussion
(Obwegeser, 2007). Chin morphology contributes to facial aesthetics as a result of the maintenance of the balance between nose, lips, chin and perioral region.

Considering these findings, when the surgeon indicates genioplasty as unique treatment in the presence of dentofacial deformities, it is probable that we will not find with harmonic and desirable results (Rosen, 1991; Posnick, 2014) as for example, in the face profiles without dentofacial changes (Park et al., 2008); the analysis of the deformities of chin must cover information of skeletal, dental and soft tissue structures (Uckan et al., 2010).

The aim of this review was to review aspects related to the history and development of the techniques of genioplasty and to recognize the diagnosis and indicate the treatment of deformities of the lower third of face.

\section{HISTORICAL PERSPECTIVE}

Currently, bilateral sagittal split osteotomy (BSSO) and Le fort I (LFI) osteotomy with a transoral approach are

\footnotetext{
${ }^{1}$ Division of Oral and Maxillofacial Surgery, Piracicaba Dental School, State University of Campinas, Piracicaba, Brazil.

${ }^{2}$ Division of Oral, Facial and Maxillofacial Surgery, Dental School, University of La Frontera, Temuco, Chile.

${ }^{3}$ Center of Excellence in Surgical and Morphological Studies (CEMyQ), University of La Frontera, Temuco, Chile.
} 
the standard procedure for the correction of dentofacial deformities. Orthognathic surgery has advanced over the years, becoming increasingly versatile and predictive for any change presented by the patient. This is due to the technicalscientific improvement, with the emergence of new concepts, associated to the development and modifications in conventional surgical techniques (Obwegeser).

he reports show that Professor Richard Trauner, in 1947, with the aid of his student Hugo Obwegeser, was the precursor of several procedures in orthognathic surgery, in the unit of Oral and Maxillofacial Surgery of the School of Dentistry of the University of Graz, Austria. Together, they operated the first patient in whom the BSSO was performed, with an intraoral approach; technique published in 1955 in Germany and 1957 in the United States (Trauner \& Obwegesser, 1957; Steinhäuser, 1996; Lee et al., 2014).

Shortly time before, until the mid-50's, the correction of dentofacial deformities of the chin was parallel to the development of maxillary and mandibular osteotomies. Advancement genioplasty was the first procedure performed to correct deformities in the chin. These corrections were performed only in cases of retropositioning with onlay grafting techniques (autogenous bone, titanium, silane and acrylic) by submental incision (Steinhäuser).

In 1942, Otto Hofer (1942) was the first surgeon to describe a technique of advancement, performed by extraoral approach through a cadaver study Gillies \& Millard (1957) performed the same procedure in 1957 in a living patient, also by extra-oral approach (Miles \& Leach, 2007; San Miguel Moragas et al., 2015).

Dr. Obwegeser knew that, just like the BSSO, there was a need for the development of a technique for a genioplasty that could be applied with a transoral approach, allowing sufficient bone contact for union and maintaining the planned advancement with the low level of resorption. The opportunity arose when a patient with significant retrogenia of the chin, but with the acceptable occlusion sought it for correction of the deformity (Obwegeser). Familiar with the transoral approach to fracture treatment, Hugo Obwegeser performed the surgical procedure with a simple cross-section of the chin, orienting the plane of the lower osteotomy posteriorly to a higher anterior bone, and advancing the bone segment.

This technique was published in 1957 and more than half a century later it is still advocated for advancement genioplasty. It is clear that from this simple conventional technique many variations appeared to correct the vertical and antero-posterior alterations of the chin, like the asymmetries.

\section{SURGICAL TECHNIQUE}

\section{A. Sequence}

Surgical sequence its common for the most used genioplastic techniques when the aim is to perform this procedure by intra oral approach (Miles \& Leach; San Miguel Moragas et al.).

Mucosal incision: The surgical approach is performed in the labial mucosa (anterior region of mandible), at least 10 to $15 \mathrm{~mm}$ of mucosa attached to the gingiva, avoiding dehiscence or ptosis of the lips. Care must be taken to identify the branches of the mental nerve, which are often visible (the incision is made more superiorly in the region of canine).

Muscular incision: The incision is then completed down to the bone. The mental nerve should be avoided where it exits from the mental foramen by not performing the incision too far posteriorly.

Periosteal stripping: Stripping of the periosteum should to maintain the periosteum intact, only to identify noble areas and perform the osteotomy safely; avoiding total denudation of the chin as this will result in unpredictable soft tissue changes.

Placement reference marks: The midline of the chin is marked in both segments (superior and continued down onto the genial segment) to provide a landmark for accurate repositioning (Fig. 1). Two other vertical references are about 5 to $7 \mathrm{~mm}$ anterior to the mental foramen. These are performed to avoid an inadequate rotation of the lower segment around the central reference during advancement, which will result in postoperative asymmetry.

\section{B. Performing Osteotomy}

In order to correct the deformity itself, we can use osteotomy (drills), grafting procedures (autogenous, heterogeneous, alloplastic) or the association of these (Park et al., 2010). Regarding to osteotomy, it is usually performed with the aid of drills, oscillating saw or piezosurgery with high potency to permit normal speed to perform. Since 1994, this technique has been widely used due to the simplicity and safety (Vercellotti et al., 2005).

After the correct positioning of the reference lines, a horizontal osteotomy is performed, which will result in a 


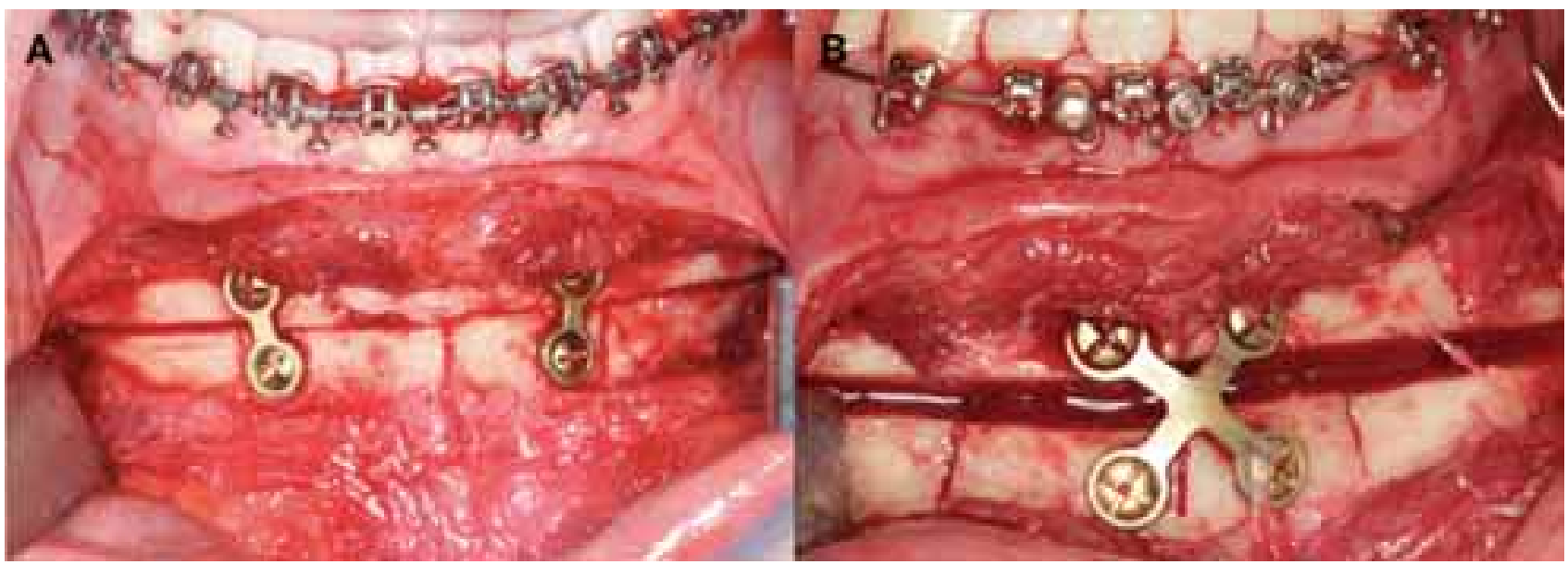

Fig. 1. The midline of the chin is marked in both segments (upper and lower segment) to provide a landmark for accurate repositioning. It is important to note that this osteotomy is performed at least $5 \mathrm{~mm}$ below the apex of the lower incisors and $5 \mathrm{~mm}$ below the mental foramen. The use of titanium plates $(2.0 \mathrm{~mm}$ system) and screws are recommended.

lower segment, which will be repositioned to correct the change in the chin. It is important to note that this osteotomy is performed in the portion anterior to $5 \mathrm{~mm}$ below the apex of the lower incisors and in the region posterior to the $5 \mathrm{~mm}$ below the mental foramen, in order to avoid damage to the nervous tissue (Thomson, 1985; Wang et al., 2007).

The design and angulation of the osteotomy will vary according to the anatomy of the subject and the desired movement (anteroposterior, vertical, transverse and asymmetry) which is determined by the type of alteration presented by the patient. The angulation of the osteotomy relative to the lower margin of the mandible should be carefully evaluated taking into account the planned motion vector. This is crucial to avoid postoperative abnormalities in the contour of the lower edge of the mandible (Schuberth et al., 1990; Shoshani et al., 1998).

In general, for only anterior augmentation or reduction of the chin, the osteotomy should be performed in a horizontal plane, so that maximum advancement is achieved without modifying the vertical height of the face. On the other hand, some osteotomies applied for vertical alterations of the chin have a greater vertical angulation (Yang \& Park, 1991; Dolce et al., 2001). The reduction of the chin can also be performed through a horizontal sliding osteotomy of the lower segment. The chin usually appears wider after this procedure and the diminution of the labiomentual groove is observed. Care should be taken so that the soft tissues accompany the bone movement, so that there is an excess of soft tissue without insertion in the mental region, and can cause ptosis labial (Hinds \& Kent, 1969).

In this stage, care should be taken with trauma to the lateral periosteum and damage to the vascular component.
After the end of the osteotomy, the segment is carefully mobilized; the distal segment should be movable and remain pediculated to the lingual musculature. Then, after their separation from the mandibular bone, the lower segment is positioned at the predetermined position in the preoperative. At this time, adjuvant procedures for reanatomization, such as segment widening / narrowing or soft tissue procedures are performed (Mommaerts et al., 2002). Trauner \& Obwegeser affirm that rectilinear advances can cause lateral projections on the lower margin and decrease of bone contact between segments. In addition, if the chin is transversely narrowed, the advancement will tend to make the face appear even sharper.

The reduction in height (removal of a preplanned segment of bone), also called intrusion or genioplasty of impaction, was first described by Reichenbach et al. (1965). This technique is applied through a wedge resection and rotation of the inferior segment superiorly. This movement causes soft tissue changes of approximately $90 \%$ when they remain attached to the lower edge. When the lower edge is resected and removed the soft tissue changes are reduced to 25-30 \% of the amount of bone removed (Reichenbach et al.; San Miguel Moragas et al.).

"Downgrafting" or genioplasty for height increase was first described by Converse \& Wood-Smith (1964), with an insertion of a bone graft at the site of the horizontal osteotomy (Fig. 2). This technique generally requires a support for hard tissue bells and a soft tissue response measuring approximately $100 \%$ of the bone variation (Converse \& Wood-Smith).

A pioneering study of the narrowing of the chin was performed by Park \& Noh (2008), which presents a bilateral narrowing of the chin for aesthetic purposes by means of a 


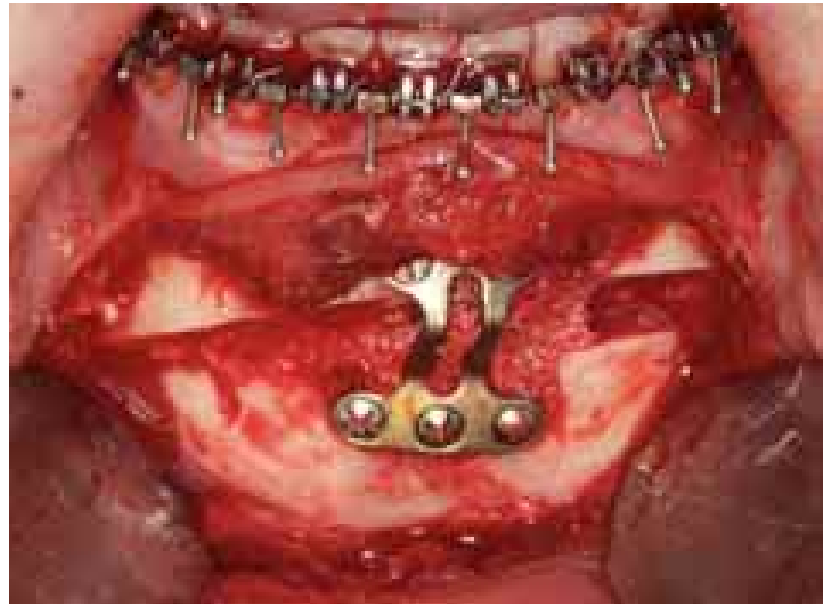

Fig. 2. Down and posterior movement of the distal segment in patient presented in Fig. 4; the stability of the movement is maintained by the bone graft and rigid fixation. horizontal osteotomy and resection removal of a bone fragment in the central portion (Fig. 3). Chin shaping, in combination with osteotomies at the angle and body of the mandible, is indicated for correction on square faces; and has now gained prominence in patients seeking facial feminization and also in patients of Asian ethnicity (Park \& Noh).

The use of genioplasty for widening is not so usual. Patients with absolute transverse mandibular deficiency are treated with symphysis widening, through the use of distractors. Epker \& Fish (1995) proposed a model of widening genioplasty with the division of the inferior segment and the interposition of bone graft. Reyneke \& Sullivan (2001) proposed a simplified technique consisting of an osteotomy in the midline of the anterior segment followed by rotation of the fragments.

\section{Options for Fixation}

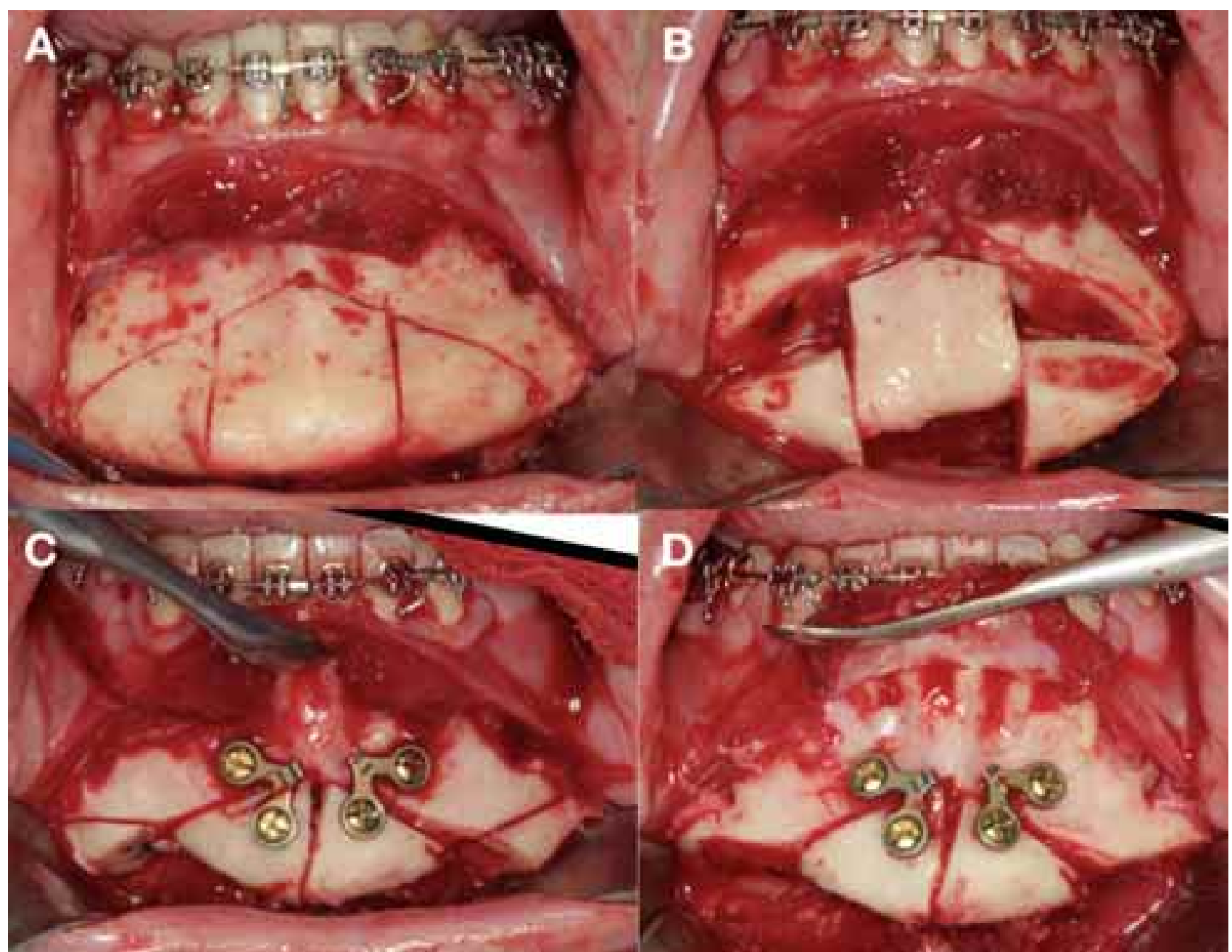

Fig. 3. Technique used for reduction of the width of lower third bases in modified genioplasty and giving a more aesthetic shape. A) Landmark of osteotomy, B) Segmentation of the meddle bone block, C) Reduction and fixation of the lateral segments and D) Zig-Zig finalization with distal osteotomy. 
Options available for fixation of the distal segment include: (Hönn et al.) two tricortical screws, (Johnston et al.) prebent genial plates and (Sinko et al.) bilateral 1.5-mm plates (Ferretti \& Reyneke, 2016).

The advancement of maxillofacial fixation techniques through the use of titanium plates and screws combined with biodegradable systems have contributed to greater treatment accessibility and lower complication rates (Lee et al.). Although the advances in biodegradable systems have been more frequent in the past, it is still limited due mainly to high cost, inconvenient handling, prolonged surgical time and still lack of studies correlating long term stability (Park et al., 1989; Lee et al.; Edwards et al., 2000; Salvino, 2010; Bhatt et al., 2010).

\section{INDICATIONS AND CONSIDERATIONS FOR FA- CIAL BALANCE}

The chin is considered in the one of the most notable structures of the face and the aesthetic contour of the lower third of face has become a frequent complaint among patients with facial deformities (Lee et al.). The positioning and shape of the lips, depth of the mentolabial groove, the soft tissue suprajacent to the mandibular symphysis and position of the lower incisive are the most important aspects to be considered for the surgical procedure of genioplasty (Olate et al., 2016). The ideal way to diagnose changes in the chin is through the frontal and profile analysis associated with facial photographs (Fig. 4) and computed tomography, noting that the decision of changes is attributed to diagnosis and clinical experience (Uckan et al.).

Among several surgical techniques used to make this facial harmony feasible, a genioplasty and its technique variations are found (Hsu et al., 2010), correcting changes in all planes (Reyneke, 2003). This procedure became widely diffused both in patients with dentofacial deformities, where it would use this technique in association with LFI osteotomy and BSSO, as well as in isolated situations of complaints by the patients in relation to the inferior third proper (Annino Jr., 1999). In this sense, soft to hard tissue ratio in the chin area is $1: 1$ in almost all the tridimensional analysis, so surgeon could expect the same movement in the soft tissue when create the bone movement (Olate et al., 2016, 2017).

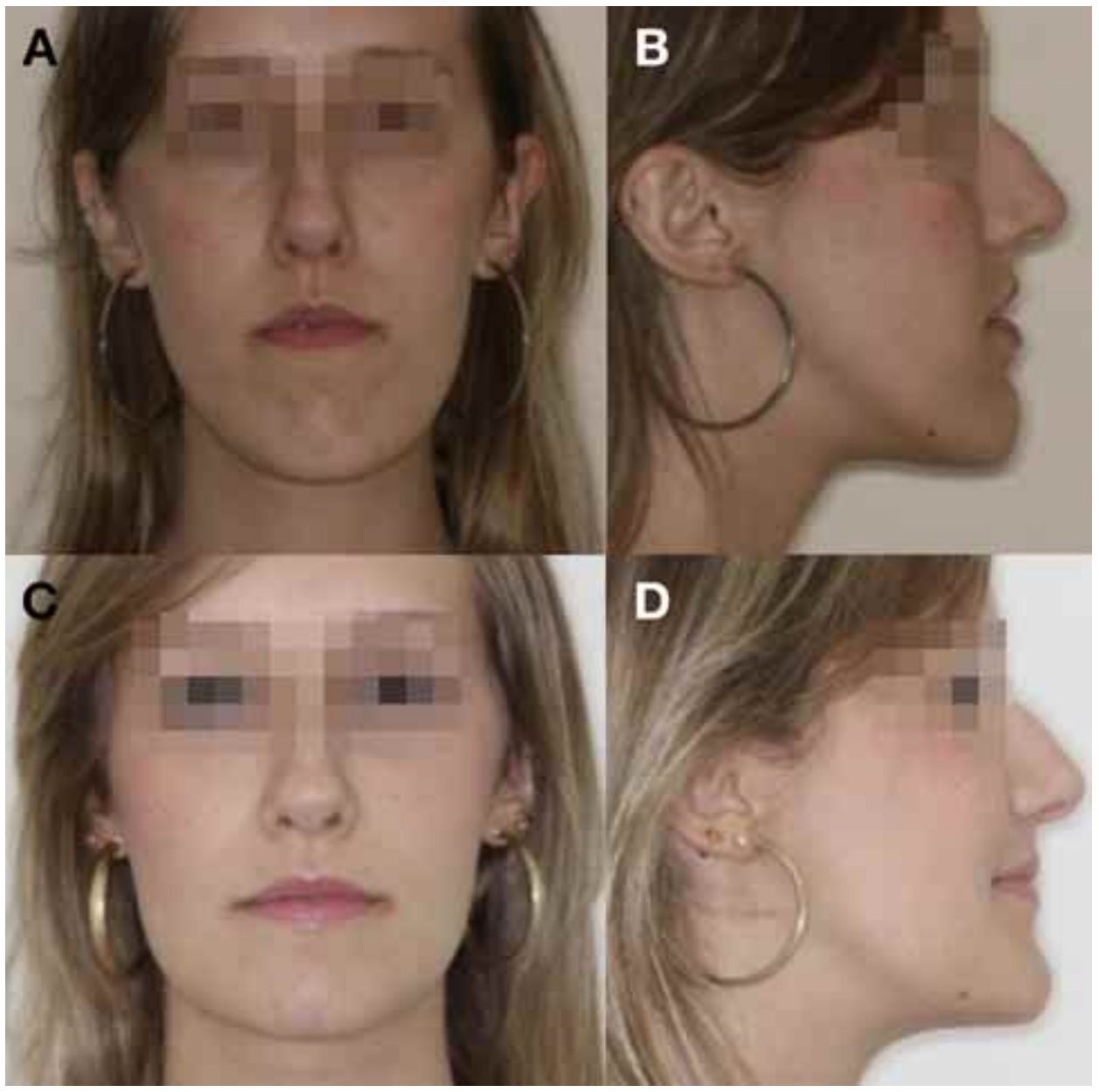

Fig. 4. Profile and frontal view in before $(\mathrm{A}$ and $\mathrm{B})$ and after $(\mathrm{C}$ and D). Advancement and reduction of height in this patient with facial deformity in association with Le Fort I osteotomy and bilateral sagittal split osteotomy could help to make a more proportional face. 
In a recent review of 262 cases of orthognathic surgery, we can see the low rate of complications resulting from this technique, with $0.4 \%$ of infections and $0.5 \%$ of gingival recessions, and no patient undergoing surgical reintervention for removal of osteosynthesis material or reoperation due to revision (Posnick et al., 2016). It is worth mentioning that other complications may be associated with loss of the osteotomized segment, bone resorption, infection, dislocation / unfavorable alignment, lower lip ptosis and damage to the mental nerves.

The surgeon should understand the indication of when to treat this type of deformity and that this indicates to the premise that harmony is more important than proportionality (Uckan et al.) (Fig. 5). A prominent jaw that culminates in a square face is considered aesthetically unfavorable as it offers the face a muscular appearance and considerably diminishes the appearance of femininity in some patients. The conventional procedure for correction of a square contour is the resection of the mandibular angle or the reduction of the mandibular bone itself, called "mandibular angle resection" or "mandibular reduction" (Baek et al., 1994; Yang et al., 1995). However, in some patients, this isolated procedure cannot make the lower third of the face thinner, due to the limitation of the technique and the possibility of damage to the mental nerves. In this specific type of situation, some surgeons have advocated the use of a surgical approach and removal of the central segment from the lower third, reducing the width and giving a more aesthetic shape (Park \& Noh). Other authors advocate the use of the technique in "zig-zag", because it allows combined movements of reduction of the vertical and transverse dimension, also allowing advancement or retreat of the chin if necessary (Keyhan et al., 2013).

In addition to the osteotomies used in the harmonization and aesthetics of the lower third of the face, a variety of techniques have been used to design the chin using grafting procedures. It is important the use of image to perform an analysis about the requirement of the patient.

In a review of 650 cases, important considerations have been made about the use of bone substitutes such as: composition, safety, hydrophobicity, surface characteristics and surgical technique (Gui et al., 2008). In the Medpor group, no infection or alloplastic reaction was found. However, two patients needed revision to reduce the implant. On the other hand, the genioplasty group experienced no infections, nonunion or malunion. Two patients underwent reoperation because of minor depressions and contour irregularities at the osteotomy site. Park et al. (2010) in a

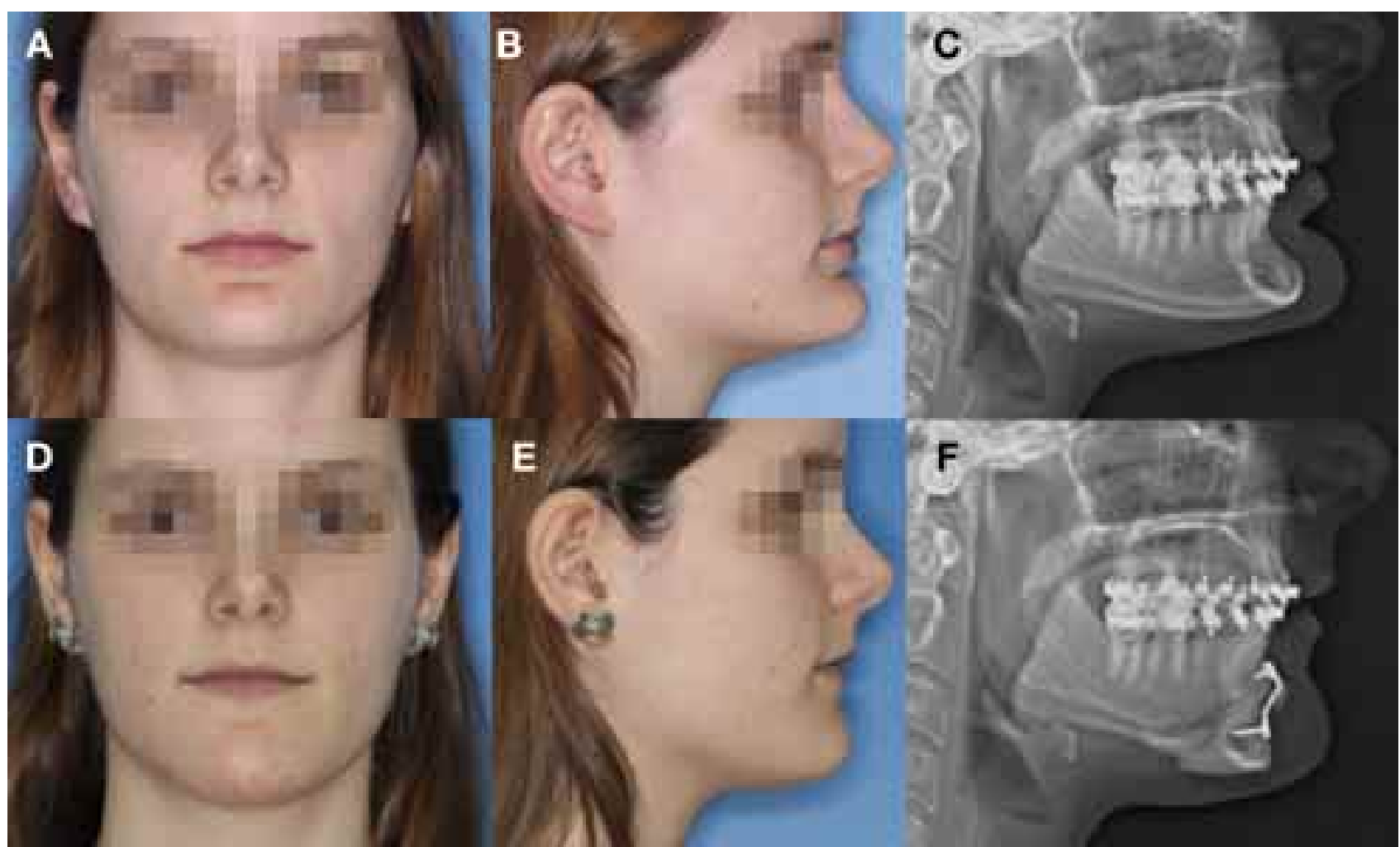

Fig 5. (A, B and C) Patient showing a low high face with chin protruded, disharmony in the mental sulcus and lips relation in a normal position; dental occlusion balanced. (D,E and F) New position in the chin, without mandibular reposition. In this case facial balance by chin surgery could leave to correct facial proportions. 
retrospective study evaluated 33 patients submitted to the genioplasty procedure and divided into groups of patients submitted to bone osteotomy and bone alloplastic substitute (Medpor). The results showed that the mean relapse rate of the most prominent or anterior point on the chin in the midsagittal plane of patients who went underwent osteotomy was $18.59 \%$, and using Medpor was $14.56 \%$.

Undoubtedly the aesthetic factor is the most discussed and widespread among the indications by surgeons and complaints some patients. However, the function should also be taken into account since the genioplasty can have repercussions in the upper airways in patients at puberty. Bedoucha et al. (2015) concluded that ventilation can be significantly improved by anteroposterior optimization of the oropharynx and velopharyngeal dimension in surgical patients when compared to the control group, suggesting repositioning of the tongue near the palate in an anterior direction; in the same direction, reposition of the chin could leave a new position of the lower lip and create a new condition for lips competence.

\section{COMPLICATIONS}

As with all surgical procedures, the genioplasty technique is associated with intercurrences such as nerve damage, wound dehiscence, infection, swelling, pain, dental complications, ptosis of the lips, bone resorption and nonesthetic results (Lindquist \& Obeid, 1988; Reyneke). Some authors have related the negative impact on the quality of life of patients with facial aesthetic changes involving the lower third when combined orthognathic surgeries were performed without manipulation of the chin (Rustemeyer \& Lehmann, 2013). In this context, it is important to state that only mandibular setback through BSSO in prognathic patients is not responsible for leaving the facial profile and thinner (Baek et al.); besides the possibility of having harmful consequences for the patency of the superior airway.

\section{CONCLUSION}

Genioplasty is a procedure that presents excellent stability and has a relatively low risk of complications. Although it is a technically simple surgical maneuver, it presents in some situations the need for technique variation, and can be applied in the correction of deformities of the lower third in patients with different facial characteristics. Genioplasty can be performed as an isolated procedure or associated with other surgical procedures in bone and soft tissue, making possible satisfactory results in the facial balance, improving the aesthetics and function of the patients.
DA SILVA, H. F.; MARINHO L. F.; SOUZA, G. A.; SVERZUT, A. T.; OLATE, S.; ASPRINO, L. \& DE MORAES, M. Sobre Cirugía del mentón (Genioplastía). Int. J. Morphol 38(4):11201127,2020

RESUMEN: La armonía facial es la consecuencia del balance entre las estructuras facial. La identificación y clasificación de las características morfológicas que están acompañando la armonía facial son mas efectivas al realizar un estudio de análisis facial. La obtención de promedios entre los tercios, corrección especial de la posición del hueso y la acomodación de los tejidos blandos son factores directamente involucrados en el balance del perfil. El mentón, contribuye significativamente en este balance. Cambios expresivos en la posición del mentón son asociados con la percepción de características fuertes o delicadas. Durante los años, una serie de estudios han sido desarrollados enfocándose en las osteotomías mandibulares y técnicas capaces de alcanzar los cambios en la posición del mentón: avances, retrocesos, extrusiones, ensanchamientos, estrechamientos y asimetrías. Este estudio pretende orientar las condiciones históricas y técnicas respecto de la genioplastia; la asociación de las características del paciente con la técnica quirúrgica pueden ser aplicadas para la corrección de las deformidades.

PALABRAS CLAVE: Mentón; Genioplastía; Cirugía ortognática; Estética facial.

\section{REFERENCES}

Annino Jr., D. J. Chin augmentation and genioplasty. Oper. Tech. Otolaryngol. Head Neck Surg., 10(3):224-7, 1999.

Baek, S. M.; Baek, R. M. \& Shin, M. S. Refinement in aesthetic contouring of the prominent mandibular angle. Aesthetic Plast. Surg., 18(3):2839, 1994

Bhatt, K.; Roychoudhury, A.; Bhutia, O.; Trikha, A.; Seith, A. \& Pandey, R. M. Equivalence randomized controlled trial of bioresorbable versus titanium miniplates in treatment of mandibular fracture: a pilot study. J. Oral Maxillofac. Surg., 68(8):1842-8, 2010.

Converse, J. M. \& Wood-Smith, D. Horizontal osteotomy of the mandible. Plast. Reconstr. Surg., 34:464-71, 1964.

Dolce, C.; Johnson, P. D.; Van Sickels, J. E.; Bays, R. A. \& Rugh, J. D. Maintenance of soft tissue changes after rigid versus wire fixation for mandibular advancement, with and without genioplasty. Oral Surg. Oral Med. Oral Pathol. Oral Radiol. Endod., 92(2):142-9, 2001.

Edwards, R. C.; Kiely, K. D. \& Eppley, B. L. Resorbable fixation techniques for genioplasty. J. Oral Maxillofac. Surg., 58(3):269-72, 2000.

Epker, B. N. \& Fish, L. V. (Eds.). Dentofacial Deformities: Integrated Orthodontic and Surgical Correction. St. Louis (MO), Mosby, 1995. pp.507.

Ferretti, C. \& Reyneke, J. P. Genioplasty. Atlas Oral Maxillofac. Surg. Clin. North Am., 24(1):79-85, 2016.

Gillies, H. \& Millard, D. R. The Principles and Art of Plastic Surgery. Boston, Little Brown \& Company, 1957

Gui, L.; Huang, L. \& Zhang, Z. Genioplasty and chin augmentation with Medpore implants: a report of 650 cases. Aesthetic Plast. Surg., 32(2):220-6, 2008.

Hinds, E. C. \& Kent, J. N. Genioplasty: the versatility of horizontal osteotomy. J. Oral Surg., 27(9):690-700, 1969.

Hofer, O. Operation der Prognathie und Mikrogenie. Dtsch. Zahn Mund Kieferheilk, 9:121-32, 1942. 
Hönn, M.; Dietz, K.; Godt, A. \& Göz, G. Perceived relative attractiveness of facial profiles with varying degrees of skeletal anomalies. $J$. Orofac. Orthop., 66(3):187-96, 2005.

Hsu, Y. C.; Li, J.; Hu, J.; Luo, E.; Hsu, M. S. \& Zhu, S. Correction of square jaw with low angles using mandibular "V-line" ostectomy combined with outer cortex ostectomy. Oral Surg. Oral Med. Oral Pathol. Oral Radiol. Endod., 109(2):197-202, 2010.

Johnston, C.; Hunt, O.; Burden, D.; Stevenson, M. \& Hepper, P. The influence of mandibular prominence on facial attractiveness. Eur. $J$. Orthod., 27(2):129-33, 2005.

Keyhan, S. O.; Khiabani, K.; Hemmat, S. \& Varedi, P. Zigzag genioplasty: a new technique for 3-dimensional reduction genioplasty. Br. J. Oral Maxillofac. Surg., 51(8):e317-8, 2013.

Lee, T. S.; Kim, H. Y.; Kim, T. H.; Lee, J. H. \& Park, S. Contouring of the lower face by a novel method of narrowing and lengthening genioplasty. Plast. Reconstr. Surg., 133(3):274e-282e, 2014.

Lindquist, C. C. \& Obeid, G. Complications of genioplasty done alone or in combination with sagittal split-ramus osteotomy. Oral Surg. Oral Med. Oral Pathol., 66(1):13-6, 1988.

Miles, B. A. \& Leach, J. L. Osseous genioplasty: Technical considerations. Oper. Tech. Otolaryngol. Head Neck Surg., 18(3):1818, 2007.

Mommaerts, M. Y.; Abeloos, J. V.; De Clerq, C. A. \& Neyt, L. F. Intraoral transmental suction lipectomy. Int. J. Oral Maxillofac. Surg., 31(4):364-6, 2002.

Obwegeser, H. L. Orthognathic surgery and a tale of how three procedures came to be: a letter to the next generations of surgeons. Clin. Plast. Surg., 34(3):331-55, 2007.

Olate, S.; Zaror, C. \& Mommaerts, M. Y. A systematic review of soft-tohard tissue ratios in orthognathic surgery. Part IV: 3D analysis - Is there evidence? J. Craniomaxillofac. Surg., 45(8):1278-86, 2017.

Olate, S.; Zaror, C.; Blythe, J. N. \& Mommaerts, M. Y. A systematic review of soft-to-hard tissue ratios in orthognathic surgery. Part III: Double jaw surgery procedures. J. Craniomaxillofac. Surg., 44(10):1599-606, 2016.

Park, H. S.; Ellis, E. 3rd; Fonseca, R. J.; Reynolds, S. T. \& Mayo, K. H. A retrospective study of advancement genioplasty. Oral Surg. Oral Med. Oral Pathol., 67(5):481-9, 1989.

Park, J. Y.; Kim, S. G.; Baik, S. M. \& Kim, S. Y. Comparison of genioplasty using Medpor and osteotomy. Oral Surg. Oral Med. Oral Pathol. Oral Radiol. Endod., 109(2):e26-30, 2010.

Park, S. \& Noh, J. H. Importance of the chin in lower facial contour: narrowing genioplasty to achieve a feminine and slim lower face. Plast. Reconstr. Surg., 122(1):261-8, 2008.

Posnick, J. C. Aesthetic Alteration of the Chin: Evaluation and Surgery. In: Posnick, J. C. (Ed.). Orthognathic Surgery Principles and Practice. Philadelphia, W. B. Saunders Co., 2014. pp.1564-612.

Posnick, J. C.; Choi, E. \& Chang, R. P. Osseous genioplasty in conjunction with bimaxillary orthognathic surgery: a review of 262 consecutive cases. Int. J. Oral Maxillofac. Surg., 45(7):904-13, 2016.

Reichenbach, E.; Kole, H. \& Bruckl, H. Chirurgische Kieferorthopädie. Leipzig, Johann Ambrosius Barth Verlag, 1965.

Reyneke, J. P. \& Sullivan, S. M. A simplified technique of genioplasty with simultaneous widening or narrowing of the chin. J. Oral Maxillofac. Surg., 59(10):1244-5, 2001.

Reyneke, J. P. Surgical technique/genioplasty. In: Reyneke, J. P. (Ed.). Essentials of Orthognathic Surgery. Chicago, Quintessence Pub. Co., 2003. pp.293-6.

Rosen, H. M. Aesthetic refinements in genioplasty: the role of the labiomental fold. Plast. Reconstr. Surg., 88(5):760-7, 1991.

Rustemeyer, J. \& Lehmann, A. Reduction genioplasty enhances quality of life in female patients with prognathism and maxillary hypoplasia undergoing bimaxillary osteotomy. Int. J. Oral Maxillofac. Surg., 42(9): 1083-92, 2013.

Salvino, M. J. Avoiding pitfalls in craniofacial reconstruction using absorbable plates. J. Craniofac. Surg., 21(1):213-4, 2010.
San Miguel Moragas, J.; Oth, O.; Büttner, M. \& Mommaerts, M. Y. A systematic review on soft-to-hard tissue ratios in orthognathic surgery part II: Chin procedures. J. Craniomaxillofac. Surg., 43(8):153040, 2015.

Schuberth, G.; Shaughnessy, T. \& Timmis, D. Mandibular advancement and reduction genioplasty. Am. J. Orthod. Dentofacial Orthop., 98(6):481-7, 1990.

Shoshani, Y.; Chaushu, G. \& Taicher, S. The influence of the osteotomy slope on bony changes after advancement genioplasty. J. Oral Maxillofac. Surg., 56(8):919-22, 1998.

Sinko, K.; Jagsch, R.; Benes, G.; Millesi, G.; Fischmeister, F. \& Ewers, R. Facial aesthetics and the assignment of personality traits before and after orthognathic surgery. Int. J. Oral Maxillofac. Surg., 41(4):469-76, 2012.

Steinhäuser, E. W. Historical development of orthognathic surgery. $J$. Craniomaxillofac. Surg., 24(4):195-204, 1996.

Thomson, E. R. Sagittal genioplasty: a new technique of genioplasty. Br. J. Plast. Surg., 38(1):70-4, 1985.

Trauner, R. \& Obwegeser, H. The surgical correction of mandibular prognathism and retrognathia with consideration of genioplasty. I. Surgical procedures to correct mandibular prognathism and reshaping of the chin. Oral Surg. Oral Med. Oral Pathol., 10(7):677-89, 1957.

Uckan, S.; Soydan, S.; Veziroglu, F. \& Ozcirpici, A. A. Transverse reduction genioplasty to reduce width of the chin: indications, technique, and results. J. Oral Maxillofac. Surg., 68(6):1432-7, 2010.

Vercellotti, T.; Nevins, M. L.; Kim, D. M.; Nevins, M.; Wada, K.; Schenk, R. K. \& Fiorellini, J. P. Osseous response following resective therapy with piezosurgery. Int. J. Periodontics Restorative Dent., 25(6):5439, 2005.

Wang, J.; Gui, L.; Xu, Q. \& Cai, J. The sagittal curving osteotomy: a modified technique for advancement genioplasty. J. Plast. Reconstr. Aesthet. Surg., 60(2):119-24, 2007.

Yang, D. B. \& Park, C. G. Mandibular contouring surgery for purely aesthetic reasons. Aesthetic Plast. Surg., 15(1):53-60, 1991.

Yang, D. B.; Song, H. S. \& Park, C. G. Unfavorable results and their resolution in mandibular contouring surgery. Aesthetic Plast. Surg., 19(1):93-102, 1995.

\section{Corresponding author: \\ Dr. Sergio Olate}

Center of Excellence in Surgical and

Morphological Studies (CEMyQ)

Universidad de La Frontera

Avenida Francisco Salazar 01145

Temuco

CHILE

Email: sergio.olate@ufrontera.cl

Received: 25-02-2020

Accepted: 16-03-2020 